\title{
ИТОГИ ВЫСТАВКИ «ФОТОНИКА. МИР ЛАЗЕРОВ И ОПТИКИ-2019»
}

14 -я международная выставка "Фотоника. Мир лазеров и оптики-2019" успешно прошла с 4 по 7 марта в Москве в Центральном выставочном комплексе "Экспоцентр". Выставка, организованная АО "Экспоцентр" и Лазерной ассоциацией, проходила при поддержке Министерства промышленности и торговли РФ, Европейского индустриального консорциума по фотонике (ЕРIC), Государственного комитета по науке и технологиям Республики Беларусь, под патронатом Торгово-промышленной палаты России. Минпромторг России, являясь координатором дорожной карты по развитию фотоники в России, оказывает всестороннюю поддержку прикладным работам в этой научно-технической области, формированию важной для страны лазерно-оптической отрасли.

Выставка стабильно растет, о чем свидетельствует размер занятой в этом году площади 2540 кв. м и участие 198 компаний из 13 стран (Австрии, Белоруссии, Германии, Китая, Кореи, Литвы, России, США, Финляндии, Швейцарии, Швеции, Японии, впервые принял участие Сингапур).

Высокий уровень достижений и возможностей современных лазерных, оптических и оптоэлектронных технологий продемонстрировали многие компании, среди них Rosendahl Nextrom, Trotec Produktion. VertriebsGmbH, Infratec, Schott, Trumpf, Eksma, Hamamatsu, Optotech Optikmaschinen $\mathrm{CmbH}$, CKLaser, Standa, Buhler AG, Scanlab, a также дебютанты выставки - Mitutoyo, Yamazaki Mazak, Suntec Laser Technology, Metallife, SON-X, TEM, Adloptica. На выставке работал национальный павильон Германии, организованный при поддержке Федерального министерства экономики

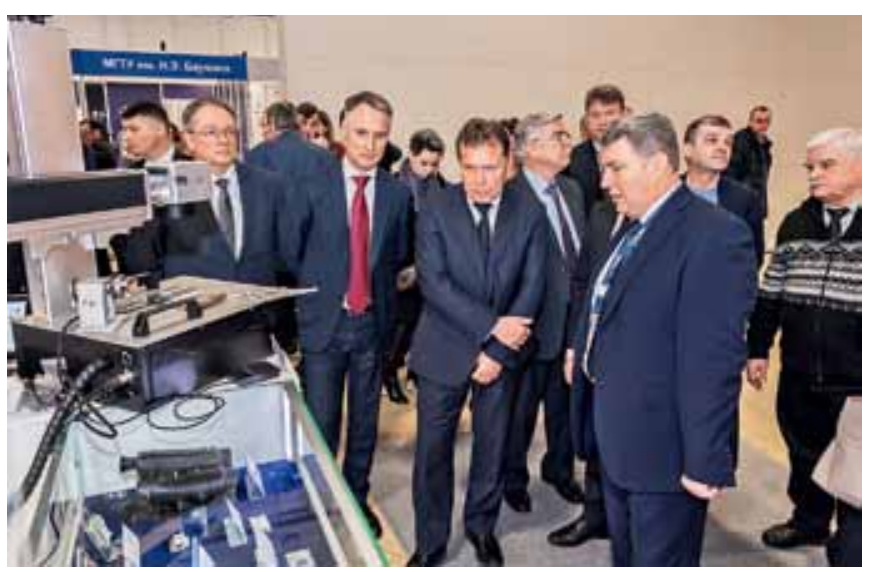

и энергетики Германии и компании AUMA. Участники из Китая и Белоруссии также представили национальные экспозиции.

Российские компании демонстрировали свою продукцию, заняв более трети стендов: Фонд "Сколково", "Лазерный Центр", Холдинг "Швабе", ГК "Лазеры и аппаратура", "Авеста-Проект", СО РАН, "Электростекло", "Викон", «Ленинградские Лазерные Системы", "Азимут Фотоникс", "Лазерные компоненты", Photonics Cloud, а также премьеры выставки - компании "Лассард", “Элком", "Хикуртек", "Гарден Групп" и другие.

Ежегодная выставка лазерной, оптической и оптоэлектронной техники является общеотраслевой площадкой, где встречаются специалисты, чтобы обменяться опытом и увидеть новые разработки. По оценкам группы экспертов, возглавляемой доктором физико-математических наук президентом Лазерной ассоциации Иваном Ковшом, 30-40\% российских участников представили свои новейшие разработки, созданные в течение года. Он подчеркнул, что выставка "Фотоника" -
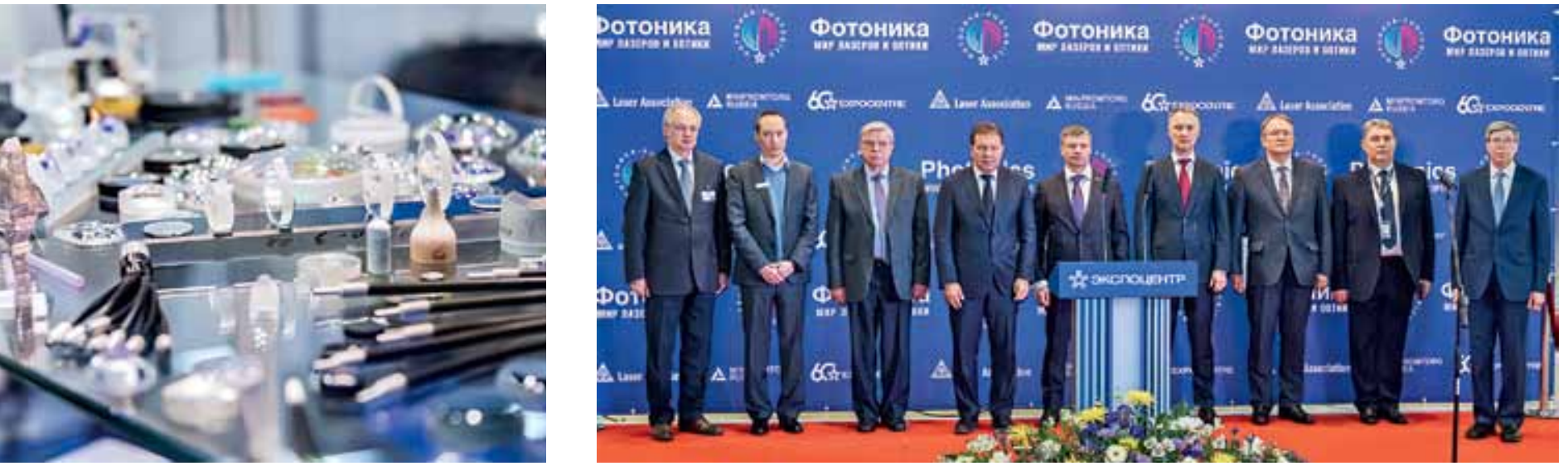


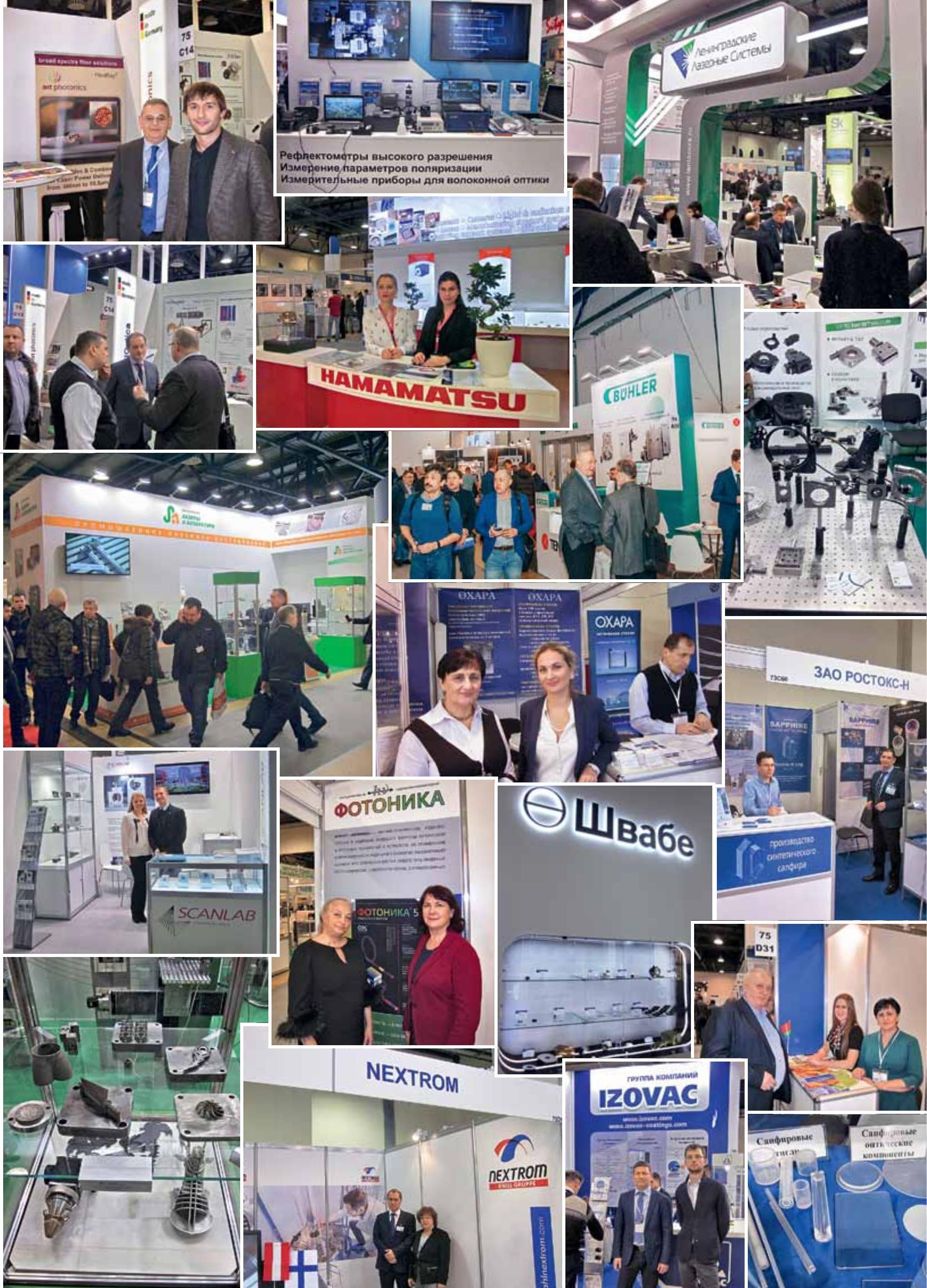




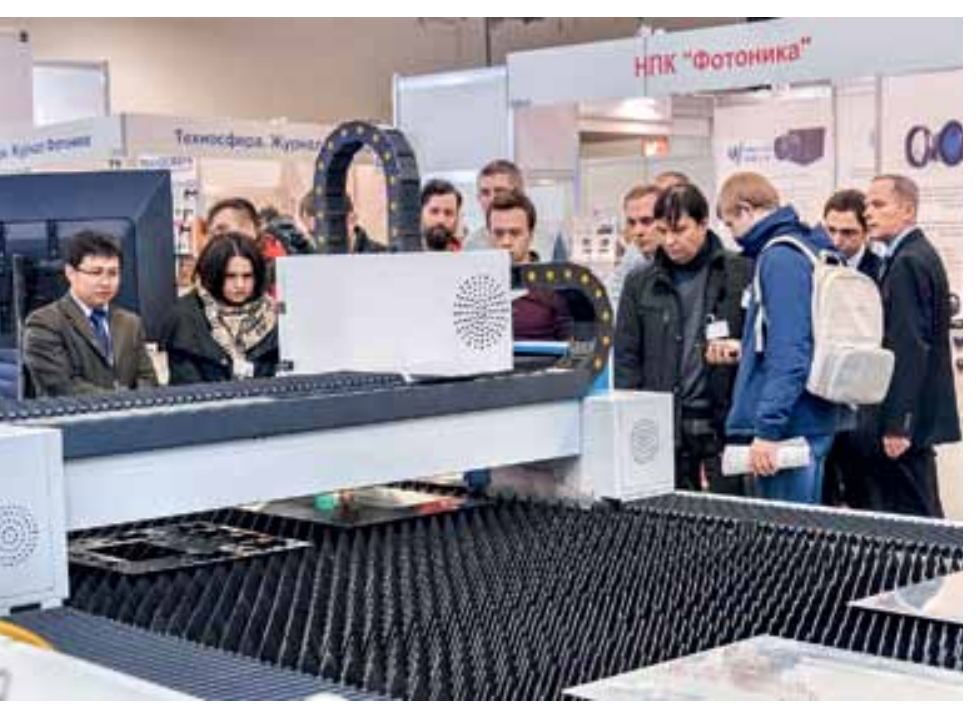

ключевое отраслевое событие, один из самых престижных форумов, который собирает профессионалов в сфере фотоники и производства лазерной техники. На несколько дней выставка превращается в центр всех контактов, встреч, обсуждений, именно здесь заключаются до $80 \%$ всех годовых контрактов. Фонд развития промышленности (ФРП) и Государственная информационная система промышленности (ГИСП) при Минпромторге России, которые впервые участвовали на выставке с информационными стендами, провели презентации своих проектов.

Выставка привлекла большое число посетителей - потенциальных покупателей экспонируемой продукции и в первую очередь пользователей техники и технологий. Общее количество посещений составило 9370 .

В торжественной церемонии открытия выставки приняли участие: заместитель председателя коллегии Военно-промышленной комиссии

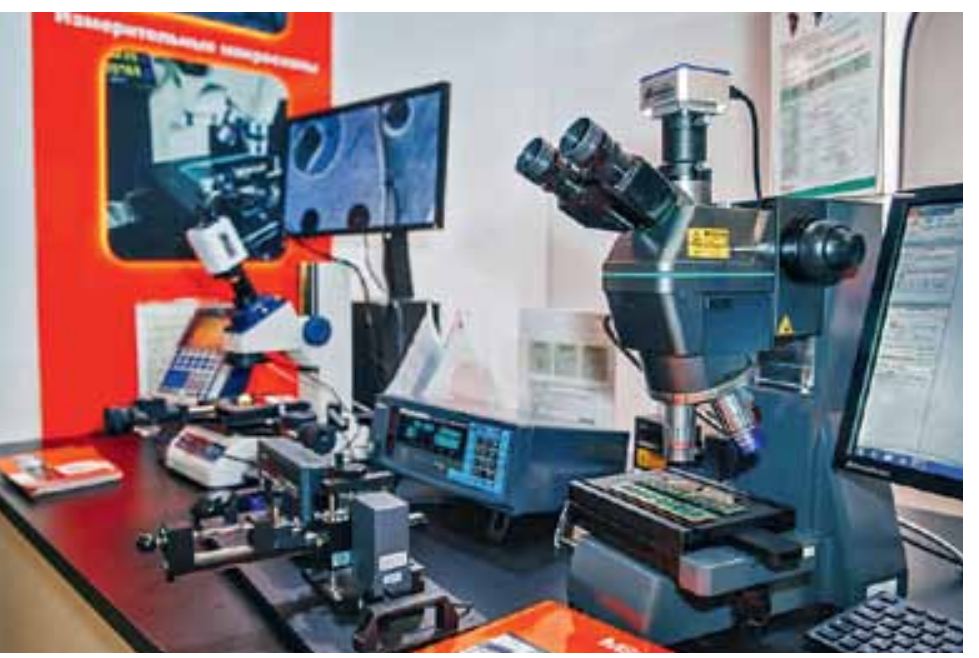

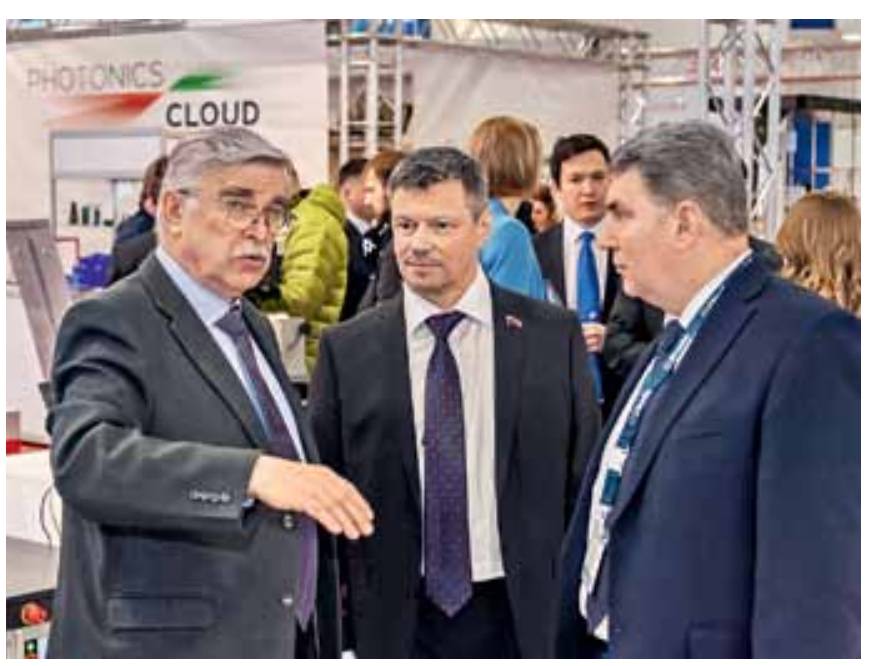

РФ Юрий Михайлов, член Комитета Государственной Думы Федерального Собрания Российской Федерации по экономической политике, промышленности, инновационному развитию и предпринимательству Андрей Ветлужских, директор Департамента промышленности обычных вооружений, боеприпасов и спецхимии Минпромторга РФ Дмитрий Капранов, заместитель генерального директора AO "Экспоцентр" Владимир Губернаторов, президент Лазерной Ассоциации Иван Ковш, вице-президент ТПП РФ Дмитрий Курочкин, первый заместитель генерального директора холдинга «Швабе» Сергей Попов, генеральный директор ЕРІС Карлос Ли, академик НАН Беларуси, председатель Ассоциации “Оптика и лазеры" Республики Беларусь Сергей Гапоненко.

Выставку «Фотоника. Мир лазеров и оптики-2019» посетила делегация Корейской Народно-Демократической Республики во главе с министром внешних экономических дел КНДР, председателем Корейской части Межправительственной комиссии по торгово-экономическому

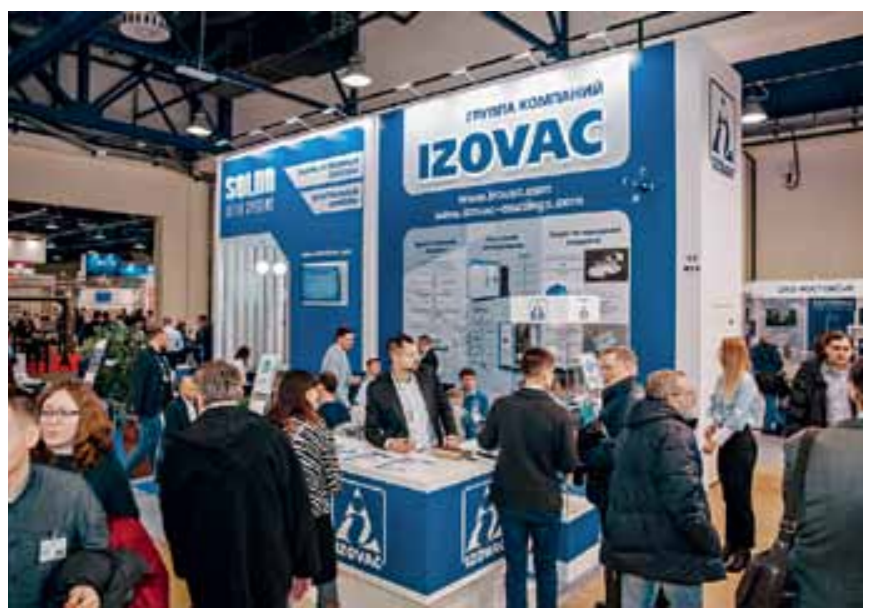




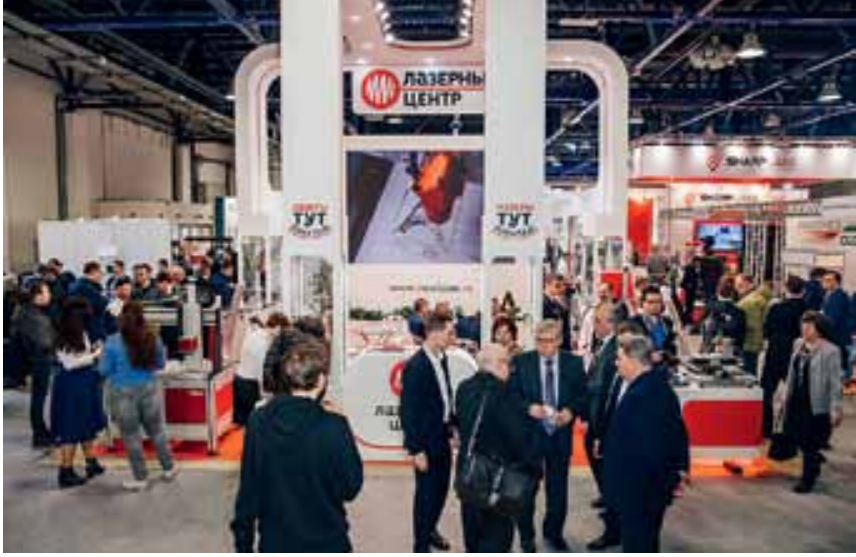

и научно-техническому сотрудничеству между Российской Федерацией и КНДР Ким Ен Джэ. Обзорную экскурсию по стендам выставки для корейских гостей провел президент Лазерной ассоциации Иван Ковш.

В этом году были представлены лазерные источники излучения и комплектующие, оптоволоконная техника, лазерное оборудование, КИА, оптоэлектроника, нанофотоника, лазерная медицина, биофотоника и многое другое.

Все дни на выставке работала ярмарка вакансий. У компаний-работодателей была возможность на специальном стенде продемонстрировать имеющиеся у них вакансии, карьерные возможности для выпускников вузов и других заинтересованных групп специалистов.

Обширную экспозицию, которая показала продукцию практически всех ведущих отечественных и зарубежных производителей лазерно-оптической техники, дополнила деловая программа,

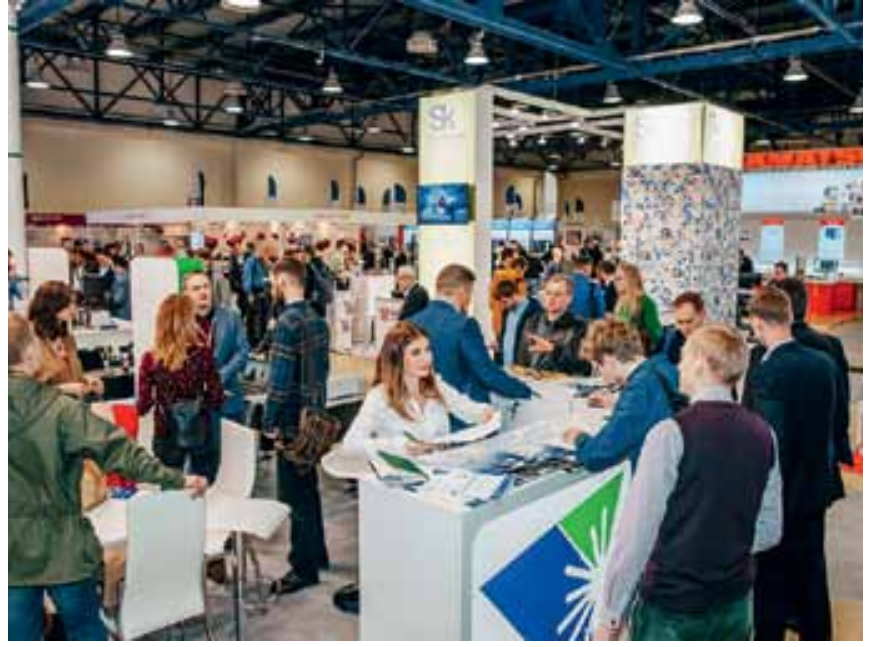

сделавшая выставку главной бизнес-площадкой отечественного рынка фотоники.

Деловую программу выставки открыло совместное заседание Рабочей группы по фотонике при Минпромторге России, Научно-технического совета Лазерной ассоциации, Секретариата технологической платформы "Фотоника", Экспертного совета по фотонике при Комиссии по ПОРО ОПК Государственной Думы ФС РФ. Темой заседания стало стратегическое развитие фотоники в аспекте нормативного и организационного регулирования. Директор Департамента промышленности обычных вооружений, боеприпасов и спецхимии Минпромторга РФ Дмитрий Капранов подробно рассказал о разработке министерством долгосрочной Стратегической программы по развитию фотоники в Российской Федерации на период до 2030-2035 годов. 


\section{КОНФЕРЕНЦИИ, ВЫСТАВКИ, СЕМИНАРЫ}

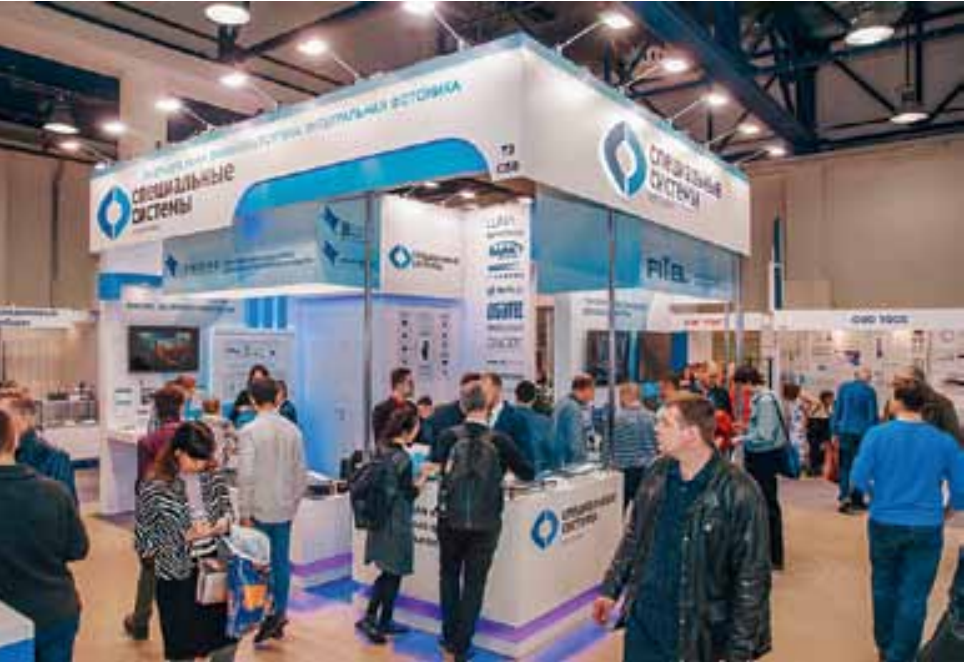

В заседании также приняли участие депутат Государственной Думы ФС РФ Андрей Ветлужских, директор Департамента государственной научной, научно-технической и инновационной политики Министерства науки и высшего образования РФ Михаил Романовский, президент Лазерной ассоциации Иван Ковш. Содержательные выступления вызвали большой интерес у специалистов.

Деловая программа была у нас очень насыщенная. В нее вошли конференции, рабочие встречи, семинары, круглые столы, в которых принимали участие представители Министерства промышленности и торговли, Министерства науки и высшего образования, Государственной Думы, ведущие специалисты отрасли. Участники мероприятийпродемонстрировали свои новые разработки, обменялись идеями и практическим опытом, познакомились с тенденциями и перспективами развития лазерного рынка.

На пленарном заседании VIII Конгресса технологической платформы "Фотоника" прошла пре-

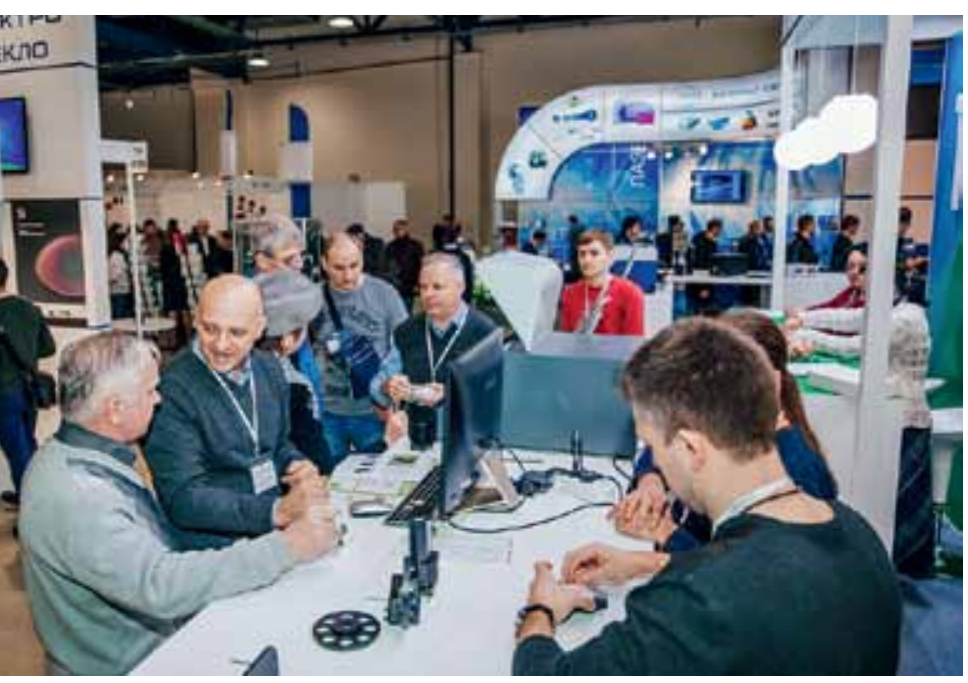

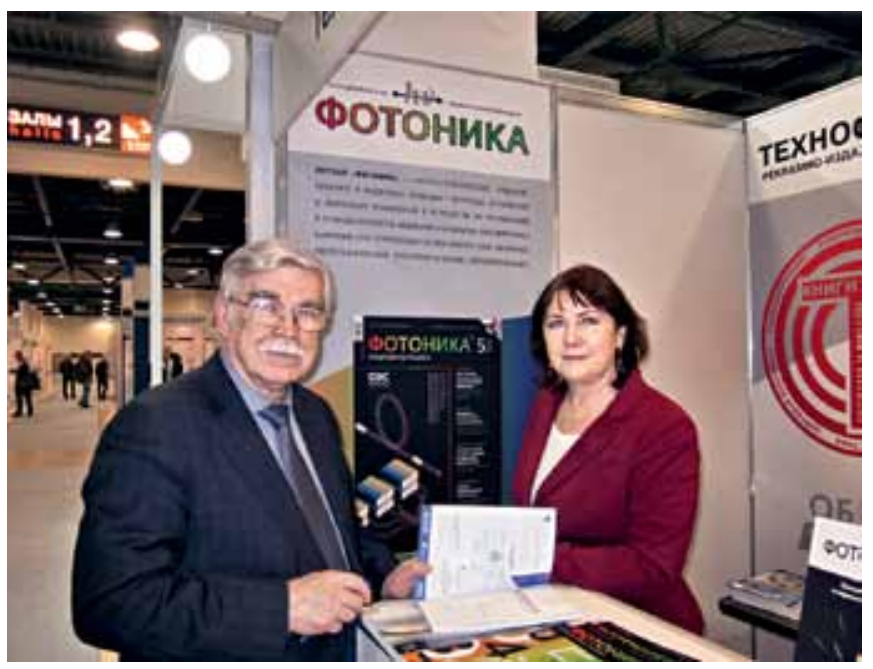

зентация терагерцевых технологий в биофотонике как нового прогрессивного инструмента неинвазивной диагностики, в том числе злокачественных новообразований. Состоялись презентации лазерных нанотехнологий, разработанных Ганноверским университетом им. Лейбница, ФРГ. Международный центр квантовой оптики и квантовых технологий представил обзорный доклад о развитии и практическом использовании квантовых технологий.

Большое количество специалистов собрали конференции, посвященные лазерным информационным системам и фотонике в навигации, недиодным источникам лазерного излучения, волоконно-оптическим линиям связи и их комплектующим.

Темами профессиональных дискуссий на круглых столах стали возможности использования лазерных технологий в производстве электромобилей, подготовка кадров в области фотоники и ее технологий.

В рамках выставки состоялись важные для отрасли мероприятия:

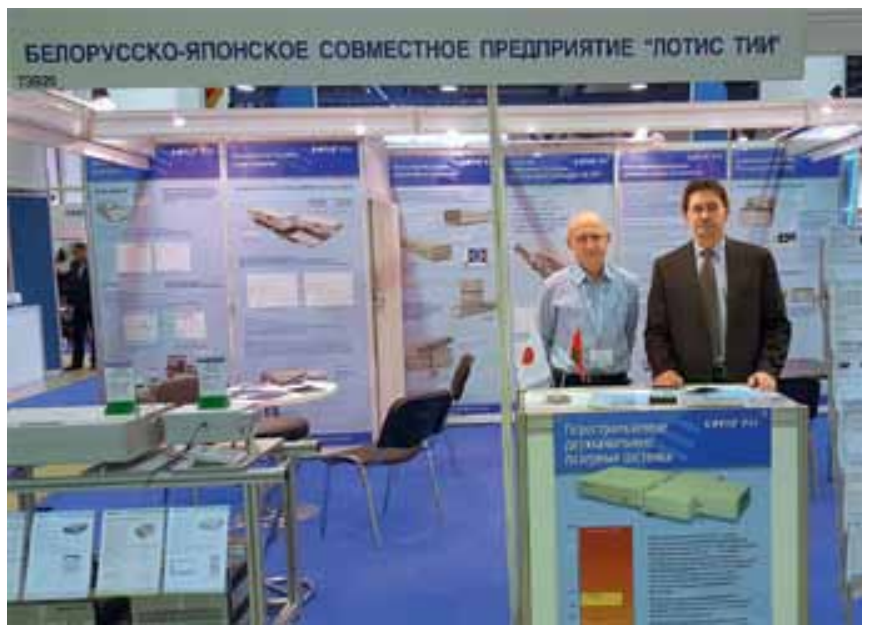


- заседание Экспертного совета по фотонике при Комиссии по ПОРО ОПК Государственной Думы ФС РФ;

- рабочая встреча руководителей республиканских и региональных центров Лазерной ассоциации с членами НТС ЛАС;

- рабочая встреча организаторов Евразийской программы "Фотоника-Агро";

- заседание межведомственного НТС при ГНЦ лазерной медицины;

- презентация Фонда развития промышленности и Государственной информационной системы промышленности;

- конкурс мастеров по номинации «Лазерные технологии в рамках движения WorldSkills»;

- вручение дипломов победителям конкурса ЛАС на лучшую разработку - на научно-практических конференциях соответствующих рабочих групп (подгрупп) ТП.

Следующая выставка "Фотоника. Мир лазеров и оптики-2020" пройдет со 2 по 5 марта 2020 года в ЦВК “Экспоцентр".

Пресс-служба АО «Экспоцентр»

Некоторые компании с удовольствием поделились рассказом о своей продукции.
Дмитрий Белов,

Генеральный директор компании "Ростокс-Н"

Компания "Ростокс-Н" специализируется на выращивании профилированных монокристаллов лейкосапфира по методу Степанова (EFG) и производстве установок для выращивания кристаллов. Компания известна своими технологиями создания из сапфира деталей со сложным профилем для использования в уникальных и серийных приборах. Каждый год мы представляем новые изделия из сапфира для различных применений: оптические элементы, защитные корпуса, стержни и колбы, герметичные крышки для контейнеров, содержащих химические и фармацевтические вещества, детали конструкции лазеров. В этом году компания приступила к производству сапфировых шариков, их назначение - детали подшипников. Мы также развиваем новые технологии - обрабатываем разные материалы, теперь помимо сапфира приступили к обработке кварца, разных марок стекол и других кристаллов. Компания "Ростокс-Н" планирует делать спаи сапфира, различных стекол с металлами, в том числе с коваром - это готовые смотровые окна для вакуумного оборудования. 
Тарас Лисовский, генеральный директор компании "ЭссентОптикс"

Компания "ЭссентОптикс" производит спектрофотометры для измерения пропускания и отражения оптических покрытий на плоских, сферических деталях, а также призмах в УФ-, видимом и ИК-диапазонах. На выставке мы представили спектрофотометр Photon RT и спектрофотометр Linza 150. Спектрофотометр PHOTON RT - единственный прибор на рынке, разработанный специально для автоматического измерения в промышленных условиях пропускания и абсолютного зеркального отражения плоских оптических деталей с покрытиями в УФ-, видимом и ИК-диапазонах. В основе конструкции лежит оптическая схема Черни-Турнера. Измерительная схема позволяет варьировать углы падения лучей и учитывает различные компоненты поляризации.

\section{Сергей Кулащик,} компания ЛОТИс ТИИ, начальник Бюро маркетинга

Наше совместное предприятие ЛОТис ТиИ было образовано белорусской компанией ЛоТис и японской компаний Токио Инструментс Инк. (далее ТИИ) и занимается производством твердотельных импульсных лазеров. Было успешно реализовано много совместных передовых разработок для японского рынка, таких как создание лазерного оборудования для нанотехнологий, получение источников терагерцевого излучения, производство лазерных систем для фотоакустической томографии, многофункциональных конфокальных рамановских спектрометров для исследований наноструктур и др.

Сочетание научно-технического потенциала сотрудников компании и опыта работы ТИИ на
Спектрофотометр LINZA 150 предназначен для измерения спектральных характеристик сферических и асферических поверхностей, то есть для линз и объективов на пропускание и зеркальное отражение. На практике из-за широкого ассортимента производимых линз в промышленных условиях часто приходится комбинировать результаты измерений, полученные по нескольким свидетелям, чтобы оценить величины оптических характеристик линзы. При этом специалистам известен тот факт, что параметры покрытий, нанесенных на линзы, отличаются от параметров покрытий, получаемых на свидетеле. Другим непреодолимым барьером является необходимость измерения характеристик отражения линзы вне оси, т.е. оценка степени неравномерности покрытия по поверхности линзы. С этой целью, применяя данные измерений отражения линзы в разных зонах ее поверхности, можно анализировать оборудование для нанесения покрытий и улучшать технологию осаждения сложных пленок.

японском рынке позволило СП ЛОТИС ТИИ разработать ряд лазерных приборов, соответствующих высоким требованиям международных стандартов, и выйти на рынки высокотехнологичной продукции, такой как твердотельные наносекундные и пикосекундные лазеры, включая перестраиваемые, а также лазерные системы и оборудование для науки, медицины и промышленности. В настоящее время лазеры СП ЛОТИС ТИИ получили известность и признание во всем мире и стали узнаваемым брэндом, который означает высокое качество и надежность.

Наиболее популярные применения лазеров СП лОТИС ТИИ сегодня это: лазеры для фотоакустической томографии, лазеры для PIV - исследований быстропротекающих процессов в воздушных потоках или в жидкостях, лазеры для PLD - осаждения тонких пленок в вакууме, лазеры для микроэлектроники и плазменной диагностики, лазеры для исследований в медицине и для офтальмологических применений.

Н.Л. Истомина, Л. В. Карякина, АО «РИЦ «ТЕХНОСФЕРА» 


\section{Синтетический}

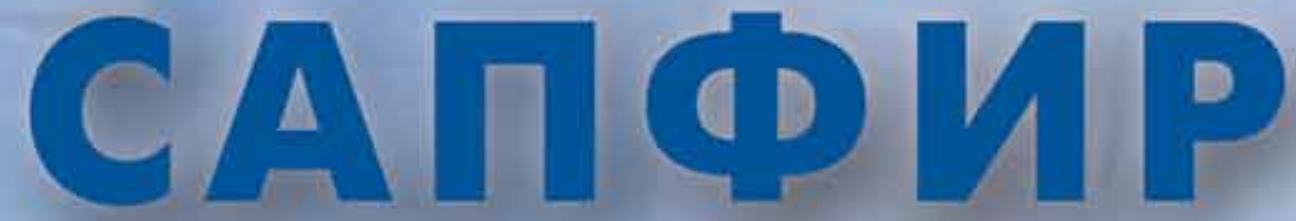

\section{Производство кристаллов и оборудования}

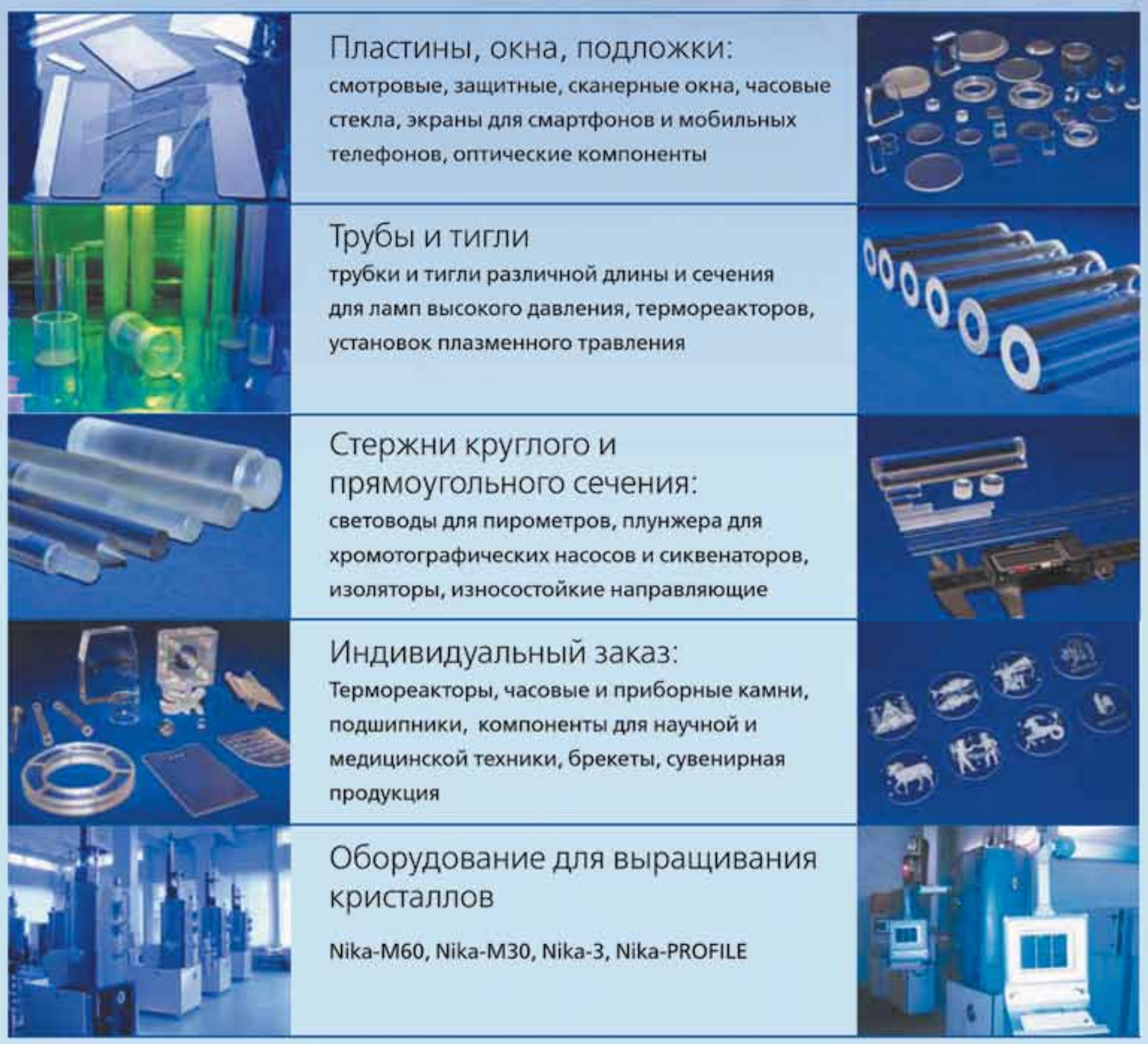

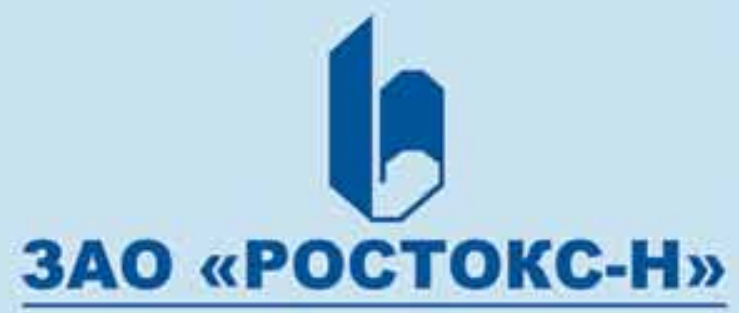

Since 1993

142432 Россия, Московская обл., r. Черноголовка, Проспект Академика Семенова, д. 9, ЗАО «Ростокс-Н» Тел.: +74965273591, +74965273596, +74965273595 • Факс: + 74965273603 